\title{
Contested boundaries : decentralisation and land conflicts in northwestern Ghana
}

Carola Lentz

\section{(2) OpenEdition \\ 12 Journals}

Édition électronique

URL : https://journals.openedition.org/apad/50

DOI : 10.4000/apad.50

ISSN : 1950-6929

Éditeur

LIT Verlag

Édition imprimée

Date de publication : 1 décembre 2001

Référence électronique

Carola Lentz, "Contested boundaries : decentralisation and land conflicts in northwestern Ghana », Bulletin de l'APAD [En ligne], 22 | 2001, mis en ligne le 15 décembre 2005, consulté le 21 septembre 2021. URL : http://journals.openedition.org/apad/50 ; DOI : https://doi.org/10.4000/apad.50

Ce document a été généré automatiquement le 21 septembre 2021.

Bulletin de I'APAD 


\title{
Contested boundaries : decentralisation and land conflicts in northwestern Ghana
}

\author{
Carola Lentz
}

Introduction

1 Administrative decentralisation and the devolution of political power to local communities have been key concepts in the recent democratisation projects in Africa. With the slogan "bring the government to the people" the Rawlings' government in Ghana announced, at the end of the 1980s, the creation of new districts. Throughout the country, this announcement set in motion intense lobby politics and political mobilisation at the local level. Population and economic viability were the most important official criteria in deciding which areas qualified to district status, but respect for the integrity of chiefdoms and ethnic groups became equally influential factors in the struggles over the boundaries of the new districts.

2 This paper will discuss one such struggle, in the former Lawra District of Ghana's Upper West Region, where the creation of new districts provoked protracted discussions, among the local political elite, concerning the political history and future of the area. There was consensus that the Lawra District was to be divided into two, or perhaps three, new districts whose boundaries were to be drawn in accordance with existing paramount chiefdoms, but there was heated debate over who should join the Lambussie Traditional Area which was too small to stand alone. This debate focussed on the connections between land ownership and political authority, including the right of taxation, on the relations between the local ethnic groups (Dagara and Sisala), and on the relevance of ethnic versus territorial criteria in defining local citizenship. In the course of these events, Sisala landowners used land as a political tool to further their interests. They attempted to force the Dagara, farming on their land, to either abandon their farms or shift their political allegiance from the Dagara-controlled paramount chiefdom of Nandom to the Sisala-controlled Lambussie Traditional Area. The Lawra District case suggests that using the concept of "traditional" local communities as the 
quasi-natural basis of grass-roots democracy, as the Ghanaian decentralisation project implicitly did, is highly problematic. It is a Pandora's box rather than a panacea for curing the evils of a distant state.

3 In what follows, I will first present some background information on the colonial and post-colonial history of the Lawra district and the difficult interethnic relations. I will then turn to the recent conflicts over district boundaries, land and political allegiance, focussing on two issues that allow to discuss more general questions of governance at the local level: the spatial delimitation of administrative units and the social delimitation of local political communities.

Difficult neighbourhood: a brief history of the Lawra District

When the Nandom Youth and Development Association (NYDA) presented its petition for the creation of a Nandom or, "if the need arises", a joint Nandom-Lambussie District to the Upper West Regional Secretary in $1986^{1}$, the Regional Secretary, a member of the chiefly family of Lambussie, was alarmed. He promised to forward the petition to Accra, because "Government stands for grass root participation and... this is what the people need". . But he also saw historical parallels between the petition and previous attempts of the Dagara chiefs from Nandom to "dominate" the neighbouring Sisala chiefdom. In fact, the outcome of the district delimitation exercise was foreseeable for anyone familiar with the history of the area. History mattered because the different parties brought it to bear on the current conflict, through their historically informed interpretations of what was at stake. But more importantly, history mattered because the long-standing problems of defining the spatial and social boundaries of the local political communities persisted. One could write an entire paper on the political use of history(ies) in the district conflict. However, I shall limit myself to a few observations that are important in order to understand the present conflicts.

First-comers and late-comers

5 In order to understand the roots of the issue of land ownership which the district conflict raked up one has to go back into the nineteenth century. What came to be the Lawra District in colonial times was then an agricultural and, in some senses, ethnic frontier. When small groups of Sisala-speaking farmers first settled in the area, is difficult to ascertain. There is agreement, however, that in many parts of the district the expansionist Dagara-speaking agriculturalists who arrived on the scene probably from the eighteenth century onwards had to come to terms with Sisala first-comers. They did so by ethnic assimilation (thus becoming members of the first-comer community), the purchase of land and earth shrines from the Sisala or their forceful expulsion. In any case the Dagara transformed themselves into allodial landowners, in full control of the land and the earth shrines.

6 This process of "autochthonisation" came to a halt with colonial pacification when property rights and ethnic boundaries were "frozen". The Dagara continued to establish new settlements on Sisala land, but they were no longer given earth shrines and were thus unable to become allodial landowners. They thus had to accept the ritual overlordship of their Sisala hosts. The precise nature of rights and duties of the Dagara "settlers" or "strangers", as the Sisala came to call them, towards their Sisala hosts, on whose land they farmed, depend on the specific circumstances of the original land grant. In some cases, bonds of friendship between the settler and his landlord make the actual burden of regular gifts very light (or even nil), and the settler's sons can expect to inherit the land (or, more precisely, the rights of usufruct). In other cases, the land 
owners exercise much stricter control by insisting, for instance, on their right to harvest commercial trees on a settler's farm or by allocating fallow land to other clients.

7 Landlord-settler relations usually were, and continue to be, an interpersonal affair. However, they can be affected by tensions between entire chiefdoms and ethnic groups, as was the case in the recent district conflicts. This is due to the fact that the boundary between first-comers and late-comers was politicized in the colonial period. The British model of indirect rule made allodial landownership, based on first-comer status, the cornerstone in defining the "native community" that was to be governed by an indigenous chief. Only "natives" enjoyed local citizenship while "strangers", such as the Dagara on Sisala land, had no right to furnish the village chief. At the same time, the boundary between natives and settlers was defined ethnically. If a newcomer to a village happened to belong to the same ethnic group as the landowners, he was integrated into the native community while ethnic strangers continued to be regarded as non-natives even after more than a generation of residency.

The creation of chiefdoms

With the exception of the small urbanised state of Wa, the north-west was not organised into kingdoms or chiefdoms in the pre-colonial period. Interacting with local actors, who were themselves interested in political centralisation and power, the British succeeded in transforming the political landscape. By 1907, the colonial officers had divided the Lawra District into ten "native states", of which some encompassed up to thirty settlements, while others included only two or three, each native state being subject to a head chief. In the early 1930s, the smaller native states were allocated to the four largest ones (later called "divisions"), Lawra, Jirapa, Nandom and Lambussie, as sub-divisions. The Lawra Confederacy which was created in this way survived the administrative reforms of the 1950s and, up until today, has marked out the framework within which local political alliances and enmities are sealed and the establishment of new districts and constituencies is disputed.

9 The divisions of the Lawra Confederacy were neither congruent with earth-shrine areas nor with ethnic groups. The extent of the chiefdoms was defined according to the power networks of the first chiefs and according to criteria of administrative convenience, but not with respect to the boundaries dictated by allodial landrights. In some places, the ritual earth-shrine territories $s$ were adjusted to the new political boundaries. However, up until the present day all divisional (paramount) chiefdoms encompass several earth-shrine areas which usually do not extend beyond the confines of single villages. This implies that paramount chiefs, in principle, have no jurisdiction over village land affairs. In practice, however, they may seek to influence land matters, as has happened in the recent district conflicts.

Chiefdoms also stood, and continue to stand, in tense relation to the ethnic criteria of group membership. Up into the 1930s the British tried to make chiefdoms and "tribes" congruent, but all such plans failed. In the end, it was a matter not of "tribes" organised into chiefdoms but of chiefdoms, whose borders were determined by factors quite different from ethnic ones, being provided with a post-facto ethnic label, according to the ethnic identity of the chief. This was how, Lambussie came to be regarded as a Sisala chiefdom and the other three Lawra Confederacy divisions as Dagara - or, to use colonial ethnic terms, Nandom came to be seen as Lobi-Dagarti, Lawra as Lobi and Jirapa as Dagarti. 
11 If the British model of native states was targeted towards the erection of small territorial states, chiefly rule in the first decades of the colonial regime was nonetheless based on personal networks with divisional chiefs controlling these networks but no territory. Their area of rule was defined through lists of the sub-chiefs and villages owing them tribute in the form of labour or goods. Only in the 1930s were political membership and rule increasingly territorialized, when a poll tax was introduced and a central treasury for the Lawra Confederacy set up (later supplemented by sub-treasuries in the four divisions). Only then, as part of an effort to draw up taxation lists, did the membership of all men to a compound, all compounds to a village and all villages to a division need to become clearly fixed. This model of a clear territorial-political allocation of all compounds, including their farmlands, to a division cut across local practice characterized by mobility and multilocality. From the 1930s onwards conflicts, especially in border zones, were sparked off by the question of to which chiefdom particular compounds should bring their political followings, and to whom farmers living in one division but having most of their farm elsewhere owed taxes.

Relations between Nandom and Lambussie

12 Such conflicts were particularly acute between the Nandom and Lambussie divisions. Due to the shortage of land in their villages of origin, ever growing numbers of Dagara farmers from the Nandom division moved on to Sisala lands in the Lambussie chiefdom. The Nandom Naa initially attempted to stop this movement because he feared losing control over the labour and taxes of his (former) subjects. Matters were, however, facilitated when in 1935 the Lambussie division came under Nandom control, following succession conflicts in Lambussie, during which the Nandom Naa was invited by the dying Lambussie chief to supervise Lambussie affairs. Out of this temporary arrangement developed a reign lasting more than twelve years, until a group of "politically conscious" Sisala demanded that the independent status of the Lambussie division be restored ${ }^{3}$. The British finally supported the Sisala claims believing that "local government is [not] likely to flourish unless the system we set up makes some appeal to the natural loyalties the people possess"4.

The restoration of Lambussie's independence in 1948 triggered off a series of conflicts. The first concerned the political allegiance of Hamile, a small market town and border post on the international boundary between the French and the British colony. Politically, British Hamile had been part of the Nandom Division; it followed the Nandom Naa through the Dagara headman in Hamile and the sub-divisional chief of Kokoligu. Land ownership in Hamile, however, was controlled by Sisala earth priests. When Lambussie regained its political independence from Nandom, the Lambussie Kuoro insisted that Hamile be included in his chiefdom because the land belonged to the earth priests of Happa, a village in the Lambussie division. His attempt to claim Hamile was supported by the majority of traders in Hamile and even the Dagara headman, who all wished to follow Lambussie instead of Nandom. After a period of conflict and negotiation, Hamile was finally placed under the jurisdiction of the Lambussie Local Council.

14 Later conflicts between Lambussie and Nandom concerned the political allegiance of Dagara farmers residing in the border zone between the two divisions. The Lawra Confederacy State Council, the district house of chiefs before which the conflicts were brought, decided that Dagara farmers living on Sisala land should pay taxes to the 
Lambussie Local Council, but those residing within Nandom territory and merely farming on Sisala land should be allowed to pay allegiance to the Nandom Local Council. However, in a number of cases Sisala and Dagara disagreed on the history of land ownership. In Dahile, for instance, the Sisala earth priest insisted that the land under his control continued to reach as far as the Black Volta, i.e. well into the Nandom Local Council territory, while the Dagara claimed that their fathers had gained allodial rights over this land which they now farmed. ${ }^{5}$ Ultimately, the Lawra Confederacy State Council decided that the Dagara compounds in question belonged to the Lambussie Local Council.

15 Yet matters did not end there. The Nandom Naa appealed to the British Government Agent and petitioned to break away from the Lawra Confederacy. This turn of events angered the Lawra Naa, the president of the Lawra Confederacy State Council, who fabricated destoolment charges against the Nandom Naa, availing himself of an initiative by the latter's local opponents. It is not possible here to go into further details, but it should be noted that these struggles over land and chieftaincy, in the mid 1950 s, became deeply enmeshed in party politics. The Nandom Naa sought the support of Kwame Nkrumah's Convention People's Party (CPP) while the Lawra Naa was one of the leading figures of the oppositional Northern People's Party (NPP). The Nandom Naa died in 1957 and did not live to see his secessionist plans fulfilled., His successor, however, struck an alliance with the first African district commissioner in Lawra, a CPP appointee from a Dagara village under Nandom, who saw to it that Lambussie and Nandom were placed together in one district, with headquarters in Nandom (1960-62). The Lambussie chiefly house had initially supported the cause of the NPP, but changed to the CPP in order to win support against Nandom hegemony. In 1962 Lambussie was indeed granted an independent district. The old Lawra Confederacy was now split into four separate districts - a politically expedient, but economically and administratively unsuitable solution to the protracted conflicts. The former Lawra District was restored after Nkrumah's overthrow (1966) and continued to function until the late 1980s when the Rawlings' government decided that new districts should be created in order "to bring the government to the people".

16 It is not surprising that many in the area felt that the NYDA petition and subsequent counter moves by the Sisala youth organisation were opening old wounds. Fears were aggravated by obvious personal continuities: the new Nandom Naa, in office since 1985, was the son of the chief against whom the Sisala had been forced to fight for their independence; the incumbent Lawra Naa was the son of the chief who had been the erstwhile Nandom Naa's most powerful opponent; and, finally, the incumbent Lambussie Kuoro had once served as secretary to the Lambussie chief who succeeded in restoring Lambussie's independence from Nandom.

The recent conflicts over districts and land: a chronology of events

17 In 1985, the Rawlings government announced that in the course of its new policy of decentralisation and democratisation, the number of districts in the country was to be increased from 65 to 110 . Three criteria were to guide the demarcation of new districts: population (not below 50,000 in rural districts), economic viability and existing infrastructure. The 1984 population census had counted 67,721 inhabitants in the Nandom-Lambussie and 88,453 in the Lawra-Jirapa Local Councils (the old census units of the early 1960s had been retained). Clearly, the population of the Lawra District was sufficient for the creation of two or even three new districts. However, Nandom did not 
reach the 50,000 inhabitants mark by itself and was therefore almost certainly in need of a partner if it was to become a new district.

Although the NYDA petition mentioned a combined Nandom-Lambussie district only as one of two possible options, this was the one that the NYDA activists actually favoured, "because after all the people of both areas have lived together for a long time and have a lot in common". ${ }^{6}$ A joint Nandom-Lambussie district had advantages in terms of infrastructure and proximity, but the NYDA also supported it because it would encompass in one politico-administrative unit the numerous Dagara from Nandom who were living on Sisala land in Lambussie villages. The Sisala politicians in Lambussie, on the other hand, preferred creating a joint district with Jirapa, inspite of the greater physical distance and other inconveniences, because they feared the dominance of the Dagara from Nandom and regarded the Dagaba from Jirapa "as friends or brothers" who "don't disturb them [the Sisala] like the Nandom people do"7

The disagreement between Nandom and Lambussie about the future district manifested itself openly, for the first time, over the question of where Hamile belonged - the very issue that had triggered off the conflicts of the 1940s and 1950s. It was probably the Lambussie Kuoro himself, a member of the National Commission for Democracy (NCD) that was in charge of defining the new districts, who had advised against NYDA's Nandom-Lambussie district project. In any case, the NCD and the regional administration decided in favour of a Lawra-Nandom and a Jirapa-Lambussie district. In March 1987, the Lawra District Secretary went on a tour of inspection in order to explain the demarcation of the new districts to the village chiefs and the local population. In a meeting in Hamile, the Nandom Naa declared that only the territory east of the Hamile-Nandom road was part of the Lambussie Traditional Area and would therefore belong to the new Jirapa-Lambussie District, while the territory west of the road was under the jurisdiction of Nandom. This claim an indignant outcry from various segments of the population of Hamile who felt reminded of the Nandom Naa's father whose severe policies towards the Hamile traders in the 1940s and 1950s had caused the town to break away from Nandom and seek to be placed under Lambussie. In a letter to the Lawra District Secretary, the "elders, tribal heads and the entire populates [sic] of Hamile" expressed their "total dissatisfaction over the wrongful claim of part of Hamile for the Nandom Traditional area by the Nandom and Kokoligu chiefs" and warned of "possible chaos and bloodshed in the event of the so-called Nandom Paramount Chief wishing to persue [sic] this shameful course ".

The Nandom Naa's claim to Hamile was almost immediately followed by the massive seizure of farms from Dagara farming on Sisala land, right at the beginning of the new agricultural season. The local NYDA activists informed the association's national executive in Wa, and the matter was brought to the attention of the Lawra District Secretary who called the Lambussie Kuoro, the Nandom Naa and the chiefs of Kokoligu and Happa to a meeting in Lawra. Confirming that according to a "High Court" decision of 1951 Hamile belonged to the Lambussie Traditional Area', the District Secretary exhorted the Nandom Naa and his chiefs to comply with the ruling that "all of the Hamile township and its environs [were] not to be divided in any way between Lambussie and Nandom". The Lambussie Kuoro, on the other hand, should "rescind his decision communicated to all his chiefs to forbid and prevent Dagartis from Nandom area farming on Sissala land" ${ }^{10}$. The Dagara chief of Kokoligu, through which Hamile had historically followed the Nandom Naa, insisted that "the ownership of Hamile" was 
the "legitimate right" of the "sons and daughters" of Kokoligu, because the land had been acquired by their forefathers "through toil and sweat" ${ }^{11}$. However, the district and regional administration stood by their decision to include Hamile in the new JirapaLambussie district, and after "peace talks" between the Lambussie chiefs and landowners and the Nandom Dagara farmers in July 1987 the new Regional Secretary was confident that the "tenant farmers" from Nandom would be allowed to "return to their farms without fear of molestation" 12 .

However, this proved to be a premature hope. The land conflicts were instead to become even more acute, propelled by the anger of the Lambussie Kuoro over renewed attempts of the NYDA, and its self-declared elitist "think tank" ANSOC (Accra Nandom Social Club), to revise the demarcated districts. In July 1987 ANSOC sent a new petition for a joint Nandom-Lambussie district, this time directly to the NCD and not to the regional administration which they believed to be biased against Nandom. Most ANSOC members were civil servants and must have hoped to further Nandom's cause through their access to the corridors of power. However, their initiative was less well coordinated on the home front. In the style of the Ghanaian rhetoric, the petition spoke "for and on behalf of the Chiefs and people of the Nandom Traditional Area". But in actual fact the petitioners had neither consulted the NYDA national executive, based in Wa, nor the Nandom Naa and much less the Lambussie Kuoro before presenting their arguments to the decision makers in Accra. The Lambussie Kuoro, assisted by the Issaw West Development Union, an almost defunct, but now revived Sisala youth association, reacted promptly. In a counter petition he declared his acceptance of government's decision for a Jirapa-Lambussie District and criticized Nandom for making "false claims to parts of Lambussie" and "false allegations" which created "a state of suspicion and mistrust... between the people of the two areas"13. Such "mistrust" made it impossible to imagine a joint district.

The NYDA executive, who had been informed of the Lambussie Kuoro's letter, insisted that there generally was no tension between the Sisala from Lambussie and the Dagara from Nandom, but only "isolated cases" of "occasional quarrels between individual land owners in Lambussie and some farmers from Nandom farming on Sisala land"14. The exchange of letters was followed in January 1988 by a series of confidential meetings, between members of the NYDA and ANSOC on the one hand and the Regional Secretary in Wa and the NCD in Accra on the other. The NCD even seems to have offered to create an autonomous district for Nandom alone, but ANSOC declined, arguing that "such a district would not serve the development needs in full of the populace to be affected in the separation of Lambussie from Nandom". In other words: ANSOC feared that the Dagara living in the Lambussie Traditional Area would suffer as a result of their administrative separation from Nandom. The Regional Secretary asked the NYDA to present some tangible proof for their claim that the majority of Sisala were actually in favour of a joint Nandom-Lambussie district. By now, tensions had increased to such a degree that even if some Sisala had ever been in favour of NYDA's district plans, they no longer dared voice this openly. All the letters and lobby politics that continued well into 1989, did not change the original decision with regards to the district. And in July 1988, Jacob Boon, a lawyer from Lambussie who had helped revive the Sisala youth association, took up his position in Jirapa as the new district secretary of the JirapaLambussie District. 

beginning of the new farming season, around April and May 1988, a sizeable number of Dagara farmers on Sisala land were again not allowed to work on their farms. In other cases, Sisala land owners requested much higher "gifts" from their Dagara clients than before, and insisted on their rights to harvest sheanut and dawadawa trees on the fields of their "tenant farmers". One conflict, in Taalipuo, a village on the border between the Nandom and Lambussie chiefdoms, became particularly prominent and attracted a lot of local and administrative attention. The basic disagreement in Taalipuo revolved around the administrative allegiance of a number of Dagara compounds, much as it did in the land conflicts of the 1950s. Did these houses belong to Lambussie, via Nabaala, the Sisala village which claimed to have given the permission to the Dagara farmers to settle? Or did they belong to Nandom, via the Nandom earth priests who likewise claimed to have established the compounds in question? The Sisala felt that these compound should pay their taxes to the new Jirapa-Lambussie District and brought pressure to bear on the Dagara farmers by refusing them permission to farm bush fields further inside Sisala territory. chiefs, organised a series of local meetings, with the affected Dagara farmers and the Sisala land owners as well as the earth priests from Nandom, Nabaala and Lambussie. However, the agreements reached remained ineffective, not least because they were challenged by competing local dignitaries who denied those present at the meeting any authority. To cite just one example: two factions of the Nandom earth priests had become deeply involved in the succession conflicts of the Nandom paramountcy in 1985 ; when one of the factions subsequently signed an agreement with the Lambussie earth priests, the other criticized this as a "sell-out" of Dagara interests. The NYDA teamed up with this latter faction and thereby strained its relations with the incumbent Nandom Naa who had been supported by the first faction. In addition, NYDA wrote letters, warning of a possible outbreak of violence, to members of the central government because it felt that the regional administration was unilaterally supporting the cause of the Sisala. This move created additional tensions, between regional and central government and, more importantly, between the youth association and the regional and district administration.

The Taalipuo conflict gave occasion to debates over the settlement history and ethnic relations in the area that went far beyond the local issues initially at stake. As the earth priests, traditionally responsible for the settlement of land disputes, were not able to resolve the matter, other institutions were brought into play: the paramount chiefs, the "modern" political authorities at the district, regional and even national levels, and the ethno-political youth associations that presented themselves as the legitimate spokesmen of the "grass roots", namely the affected farmers. However, the web of intrigue and lobby politics, at various political levels, as well as ethnic tensions and chieftaincy struggles were so complex that none of these institutions succeeded in resolving the conflict. The Taalipuo and other Dagara farmers on Sisala land were once again denied access to land during the 1989 agricultural season.

The Gordian knot was finally cut by the Catholic Archbishop of Tamale, Peter Dery, a man from the Nandom Traditional Area, of mixed Dagara and Sisala ancestry, who commands much respect throughout the region. After some preliminary talks with both sides, the Archbishop managed, in January 1990, to summon the Nandom and 
Lambussie paramount chiefs to a meeting in Hamile, on the "neutral grounds" of the Catholic mission but precisely in the town where the dispute over the district boundaries began. Dery drastically reduced the complexity of the conflict by focussing on the Taalipuo issue. He treated the district matter as closed and avoided entering into any of the intricate debates on the settlement history and ethnic relations, but reminded the chiefs and others present that "land is the creation of God for the use of human beings". The chiefs eventually agreed that three of the disputed Taalipuo compounds were to be placed under the jurisdiction of the Lambussie District and that, in turn, "the Lambussie Traditional Area will revoke all existing seizures of farm lands of immigrant and settler farmers" 15 .

The agreement was criticized by some NYDA activists who felt that the Archbishop had betrayed the Dagara interests, on the grounds that it did not prevent Sisala landowners from imposing ever harsher conditions on their Dagara tenants. However, the Taalipuo compounds in question complied with the stipulations and most affected Dagara families were relieved to finally be allowed to work their farms. Up until the present, no further land conflicts have erupted in the area. On the other hand, Nandom's aspirations for its own district, separate from Lawra, continue to be frustrated. And what was particularly bitter for the NYDA and ANSOC activists, was that when new constituencies were drawn up for the parliamentary elections of 1992, it was Lambussie, but not Nandom which was granted a separate constituency.

Earth shrines, chiefdoms and districts: defining the spatial boundaries of administrative units

28 One of the issues at stake in the Taalipuo conflict was the spatial delimitation of the new districts and the nature of administrative boundaries. Local administration must necessarily define the extent of its territorial reach. Administrative boundaries are relevant, among other reasons, for matters of taxation and for the creation of infrastructure. In the conflicts between Nandom and Lambussie one of the questions that was controversial concerned the precise course of the new district boundary. I shall briefly explain why this question is so thorny.

As already mentioned, chiefly rule in the first decades of the colonial regime was personal rather than territorial. It is no coincidence that the British officers never attempted to draw up a map with the precise boundaries of the chiefdoms. Chiefdoms were defined through lists of the sub-chiefs and villages subordinate to them. This practice continued into the 1950s, when local and district councils were defined on the basis of the existing chiefdoms. Again, I have never come across a map for that period which shows precise local council and district boundaries. Today such maps exist, but it seems that the administrative boundaries are drawn in a rather off-hand fashion, using, wherever possible, natural features such as small streams, and making sure that the villages in border zones are included in the "correct" district. District boundaries have never been demarcated on the ground. Any such exercise would undoubtedly cause unending discussions, as can be gleaned from the conflicts that often develop over the placement of signboards with village or district names along the roads.

In colonial times, the boundaries of chiefdoms and districts were defined pragmatically. For the maintenance of the roads, for instance, neighbouring villages were made to agree on a specific spot on the road, easily recognizable by some landmark such as a stream or a big tree, up to which each side would work. Such places came to be regarded as indicators of the relevant administrative boundaries. In the Taalipuo 
conflict, the Dagara invoked such a spot on the road between Taalipuo and Nabaala as proof that their forefathers actually owned the disputed land and that the village belonged to Nandom. However, the Sisala did not accept this claim, and insisted on their status as first-comers. They reminded the Dagara that it was the Lambussie earth priests who had once given Nandom its earth shrine and that therefore no substantial boundary existed between these two areas and, consequently, between Taalipuo and Nabaala. What counted, in their eyes, was that the Sisala from Nabaala and Billaw had given the Dagara permission to settle in Taalipuo ${ }^{16}$.

This argument points to an alternative basis for demarcating administrative units, namely in accordance with those boundaries set out by allodial landownership. The idea that specific political rights ensue from first-comer status and property ownership was central to the British model of native authorities. In practice, however, various historical circumstances led to situations in which the chieftaincy was not always in the hands of land owners. But as we have seen in the case of Hamile, first-comers used this model in order to bolster claims to rights of political control. This indeed is what subsequently came to bear in the district conflict, in which the Lambussie-Kuoro was convinced that the Taalipuo compounds located on Sisala land belonged to the newly created Jirapa-Lambussie District. It was thus argued that district boundaries should be drawn in accordance with those boundaries dictated by property rights.

Yet these property boundaries are by no means straightforward and uncontested. For one, debate may arise over the assignment of first-comer status and the legitimacy of subsequent property transfers. If, for example, the Sisala claim that the land up to the Black Volta belongs to them, then it is for one of two reasons. For one, they claim that even after an earth shrine has been transferred to the Dagara, the shrine-giver ultimately retains some rights over the territory. For another, they may claim that the appropriation of land by Dagara was not legitimate. While it is true that in the last quarter of the nineteenth century violence played an increasingly important role in Dagara expansion, does this justify demands to revise property rights in times of peace? A member of the NYDA executive compared the situation to that in the Middle East: "They [the Sisala] were kind of the original settlers in the area. When our people [the Dagara] came, they drove them farther and farther away... That is the story with the Israelites and the Arabs now, you conquer, you fight somebody and get his land, and then later on the man comes back and says that because there is peace now, just give me back my land. This is the problem" ${ }^{17}$. The disagreement between Sisala and Dagara regarding the history of land ownership had little effect on day-to-day access to farmland. The issue, however, did become a virulently contested one in the context of discussions over district boundaries as these fuelled fears of expulsion and loss on both sides

Furthermore, as the Taalipuo conflict has shown, the actual village boundary demarcations, along which district boundaries were to be oriented, are often contested. In most agricultural societies, including those in the Black Volta, field boundaries are held to be linear. Often they are marked, be it by notches on trees, by paths or by shrubs. In contrast, the boundaries of village - or, to be more precise, earth-shrine territories were seldom, if ever, imagined as linear. When land was plentiful, the earth shrine was probably seen as a field of ritual power, with a well-defined centre (the shrine) located in the inhabited and regularly cultivated space, characterised by concentric circles of influence, thinning out towards the uncultivated bush beyond 
which the neighbouring earth shrines lay. The bush was a zone of contact rather than separation, and earth-shrine borders were not imagined as a linear boundaries, but as a series of "meeting points" in the bush, marked by hills, rivers, rocks, ponds or specific trees. In case of armed conflict between neighbouring settlements, these meeting points could become ritually loaded if the conflict was ended by a peace-making ceremony. As more and more bush was cultivated, the boundaries between earthshrine areas had to be defined more precisely. Near the border, the ritual allegiance and village membership - of houses and fields was usually defined according to which earth priest had originally given permission to cultivate or build. The social networks of these spiritual services were, and still are, interpreted topographically. That is why, in the Taalipuo conflict, debate was so intense as to which earth priest - the one from Nabaala or the one from Nandomkpee - had given the compounds in question the right to settle. Because these service relationships often encompass numerous aspects (including the right to build houses, to farm, and to bury the dead) and are by no means unambiguous or unchangeable, the spatial allegiance of a compound is not always univocal. The inhabitants can, depending on the context and interests, refer to different services as evidence for property rights.

Whether one refers back to colonial history and its pragmatic arrangements regarding road construction or back to property rights, in either case the spatial demarcation of districts is potentially controversial. Such ambiguities are open to a variety of interpretations, which themselves are subject to negotiation. This process, in turn, is influenced by local power relationships as well as the mobilisation of regional and national political contacts.

"Natives" and "strangers" or Ghanaian citizens? The social delimitation of local political communities

The question of the spatial demarcation of districts cannot be addressed without looking at the social and ethnic composition of the local political community. In the district assemblies, which the NCD wanted to establish under its decentralisation and democratisation policy, district inhabitants all have the same fundamental rights and duties. As a citizen of Ghana, one has the right to political participation and should contribute to the development of one's home region (i.e. the area in which one resides). Differences in ethnic identity and questions of autochthony - the distinction between "natives" and "strangers", constructed by the British model of native authorities - are systematically ignored. It is exactly this model of political participation by citizens with equal rights, to which NYDA and the Dagara generally referred. Because the Dagara in the meantime had come to constitute a majority of the population in the Lambussie Traditional Area, they finally even proposed a plebiscite to settle the matter.

Sisala politicians, on the other hand, vehemently blocked such attempts, citing specific rights, which arose out of their status as property owners and first-comers to the region. Furthermore, they used their rights of disposal over the land to emphasize their position with regard to the question of the district - this being the most powerful means of exerting pressure on the Dagara, who tend to be less well-endowed with land. The Sisala fear that equal participation of Dagara and Sisala in a common district would ultimately only buttress Nandom's superiority. At the heart of these powerful sentiments are tensions arising from the unequal development of Nandom and Lambussie. The Dagara of Nandom are not just more numerous than the Sisala, but also have - due to extensive conversion to Catholicism - enjoyed earlier and more extensive 
access to education than the Sisala. They have, therefore, had more success than their Sisala counterparts in securing a wider variety of employment opportunities as well as bringing more infrastructure into their villages and into Nandom. Sisala politicians also view the Dagara as being more skilled at lobby politics and as using this advantage to "take land away" from the Sisala. This is why they wish to block the establishment of a common district at all costs, as well as institute a system under which the Dagara are forced to pay for the land in Lambussie, which they cultivate - taxes, if they live in the Lambussie Traditional Area, or a kind of rent should they only cultivate fields there.

In a letter to the government in Accra laying out the arguments against a Nandom-

Lambussie district, the Regional Secretary summarised the Sisala position as follows :

...the petition of the Nandom people to retain Nandom and Lambussie in the same District is very logical and I must add that it is really necessary if that area is to achieve its full potential for socio-economic development. Unfortunately the area is populated by two distinct ethnic groups, the Sissalas and the Dagaaba. If the two ethnic groups are to belong to one District there must not be indications that one of these is opposed to such an arrangement. In this case there was clear and uncontroversial evidence that the Sissalas of the Lambussie Traditional Area are totally opposed to being in the same District with the Dagaaba of the Nandom Traditional Area. They foresee such a situation as the then edge of the wedge which will inevitably be followed by the loss of their lands which the Dagaaba covet, and of their identity because of the numerical advantage of the Dagaaba.

The Dagaaba [=Dagara] are more politically conscious. The Dagaaba are better educated. The Dagaaba are in more dispersed, prestigious employment and in influential positions, have numerous country-wide contacts and are thus formidable lobbyists. Even in the Lambussie Traditional area itself the Dagaaba outnumber the Sissala. The one trump card held by the Sissala is that the Sissala are the traditional landowners of the Lambussie Traditional Area and even claim ownership of most land in the Nandom Traditional area. A number of prominent Sisala have seen the move for the two Traditional Areas to belong to one District as an attempt by the Dagaaba to colonise them and take over Sissala land.

... I am aware that if a straight referendum were to be held in either of the two traditional areas as advocated by the Nandom Youth and Development Association, the result would be in favour of the creation of a Nandom-Lambussie District. The Dagaaba would vote solidly for and the Sissalas against... The pertinent question is whether a decision based on the result of such a referendum would promote the stability and development within such a District. ... the majority is not always right and a decision based on the majority principle may turn out to be nothing less than a tyranny of the majority. ... The Sissala are in the minority, but a significant minority whose aspirations cannot be brushed aside without dire consequences for the peace and progress of the area... The Sissala should be coaxed and not coerced to accept the creation of a Nandom-Lambussie Distric ${ }^{18}$.

For the NYDA activists this reference to settlement history was unacceptable, or, at the very least, one-sided. They insisted for one that it was unjust to continue classifying someone as a "settler" after more than sixty years of settlement, effectively excluding them from full political participation. Furthermore, they made use of a classic argument in land rights discourse, namely that ownership rights, and therefore rights to political participation, ensue from the active cultivation of the land. Finally, they saw the emphasis of ethnic difference as a political strategy on the part of a small Sisala elite, on the grounds that "the vast majority of ordinary people are quite capable of making up their minds without resorting to ethnic identities". All the technical issues infrastructure, development potential and democratization opportunities - favored a 
joint Nandom-Lambussie District. In their comments to the above cited Regional Secretary's letter they wrote :

How really distinct are the two ethnic groups... [Dagara and Sisala]...? These are people who have lived together for more than a century. There have been intermarriages between the two... Also the two communities have always shared common social and economic infrastructure such as a daily market, a rural bank, health care, educational facilities etc. Our suspicion therefore is that the animosity between the two areas [Nandom and Lambussie] is being deliberately fanned by some individuals who think that their personal amibitions are best served that way. It may also be pointed out that after so many years of living together, sharing things in common, it cannot be said that the Sissalas have lost their identity and been colonised by the more populous Dagaaba. So why then suddenly these fears for their identity?...

If anything, at all, it is the Dagaaba in the Nandom-Lambussie area who stand in the danger of having their land rights undermined. of all the land seizures and coveting of land in that area can the Regional Secretary point to one instance where our people have seized or coveted Sisala land? Most of the Dagaaba in the NandomLambussie area have made the place their home since the early part of the 19th century. The Sissaala are themselves who migrated into the area from somewhere else. They did not germinate from the ground in the area. The fact that they arrived before us and established a few communities in the wild bush that the area was at that time does not justify the landowner-tenant relations that some would like to see existing between the two areas. In fact, the pioneer Sissala settlers could not have tamed and put under cultivation the wild bush that the area was without the Dagaabas. Descendants of these intrepid conquerors of the land cannot now be dismissed, generations later as mere settlers, as is now currently happening in Taalipuo... $^{19}$

In an unsent letter the NYDA cited the Ga in Accra as a positive example for how both the "autochthonous" rights of cultural self-determination as well as immigrants' rights to political participation could be upheld: "When the Gas have their purely traditional performances, customs and cultures they do it alone, but when it concerns Government and other issues emanating from Government for the general concern of the people in Accra, all residents in Accra decide on it" ${ }^{20}$. Whether the situation in Accra really developed as idyllically as NYDA would like us to believe, is a matter of serious doubt, especially in light of the numerous property disputes and the debates as to the "correct" ethnic identity of parliamentary candidates or city council members. The reality is that everywhere - in Accra as well as in rural areas with large immigrant populations - debates are becoming increasingly important as to which economic and political rights are to be derived from the status of an autochthone or a first-comer. In case after case we see that the main issue in this context is land control.

The Upper West Regional Secretary, who in the letter cited was sympathetic towards Sisala fears for their land, became more critical in subsequent weeks, possibly in light of the on-going Taalipuo conflict, or perhaps in response to pressure from the capital city. In a speech held before the new Jirapa-Lambussie District Assembly he did not blame Sisala claims of ownership per se, but rather blamed "alien and negative land tenure practices" for the land conflicts. In doing so, he constructed a romanticised view of traditional land rights, which bears little resemblance to local realities :

...the relationship between immigrant farmers and the landowners was never one of servant and overlord. More so, ownership of land was never used as a means of subjugating the landless. 'Permission to use land for farming was invariably granted 
by landowners, no fees were charged, no percentage of produce was exacted and no act of allegiance to the landowner was requires as [is] the case today'... ${ }^{11}$ Lambussie Kuoro insisted that Sisala landowners would have real concerns regarding future access to land :

The land is becoming short. When people were farming just some small acreages, there was land. Now somebody who was doing about ten acres will do, say, about hundred, using bullocks for ploughing. Somebody who was doing about two, will now do about fifty. So you will find that the consumption of land is now greater, so definitely it will become short. Our people have realized that they can make a lot more income from farming instead of going down south to burn charcoal. So people who were down south have now moved up here to farm. Now secondly, people feel that they have to reserve their land because the cost of inputs are now very very high. So if you give up all your land and it is exhausted, you yourself will have nowhere to $\mathrm{go}^{22}$.

Archbishop Peter Dery argued similarly and made reference to the area's settlement history- it was for this very reason that NYDA activists accused him of betraying Dagara interests at the peace talks in Hamile. Dery's position, however, concurred with that of the NYDA in so far as both saw that land was not the only issue being debated, and that political relations as well as ethnic discrimination were also central concerns :

Recently, the Sisala are trying to punish the Dagara for the discrimination they suffer, by taking away the land from Dagara farmers who are farming on Sisala land. It is very clear that all the land between the Kambah and Hamile belonged to the Sisala when the Dagara moved into the area. The Dagara were fighters and pushed the Sisala further and further eastward until at a certain point, a boundary needed to be established to stop the fighting. This boundary gave the more plentiful and better lands to the Sisala, and when the Dagara had filled their place between the Black Volta and this boundary and were lacking land to farm, they asked the Sisala for land to farm. They were given land to farm and in return had to give some produce to the Sisala. In most cases, apparently this was done only once, at the beginning of the contract... At a certain point, however, Dagara farmers were complaining about Sisala landowners that they were lazy and demanded too much from them, and they no longer wanted to give the Sisala any produce. The Sisala reacted by seizing their lands, and the political problem developed. [...] The root of the problem really is the discriminatory attitude of the Dagara towards the Sisala. The NYDA 'young men' have had their second thoughts and planned to pull Bussie [Lambussie] under Nandom, and since Nandom is numerically much stronger than Bussie, Bussie would have been swallowed. They are trying to revise history, for instance in the Hamile case ${ }^{23}$.

This is exactly the central point that was, and still is, up for debate: does a political community, which exercises effective political control in a given district, define itself historically or does it constitute itself through the idea of fundamental equality, regardless of the historic development of land ownership, and looking to a shared vision of the future? Mahmood Mamdani (1996) declared the difference between "citizen" and "subject", which he views as the most important legacy of the colonial "bifurcated state" and the decentralised despotism of the "native authorities", as the defining characteristic of the African organisation of power. But as can easily be seen in the case presented here, Mamdani's view of colonial political organisation as one based on "tribes" is too simplistic and his association of the citizen-subject binary with the rural-urban dichotomy inaccurate. Furthermore, analogous debates regarding the legitimate basis of political participation took place in seventeenth and eighteenth 
century England. The idea that voting rights need to be tied to property ownership, because migrants and non-landowners are subject to a multiplicity of loyalties and therefore regarded as unreliable and potentially irresponsible, was a topos common well into the twentieth century. Ultimately up for debate was the question of which forms of political community could be established on the basis of mobility and multilocality - a question not even raised in the current decentralisation-mania in Africa.

Closely tied to these questions is an issue, which I can only mention here, but on which I do not have sufficient time left to elaborate: namely the extent of legal pluralism and the role of (neo)traditional institutions such as chieftaincy vis-à-vis elected district assemblies or youth associations in local government and mechanisms of conflict resolution. The conflicts between Lambussie and Nandom in particular make clear the problematic nature of the idealistic support voiced by numerous politicians of decentralisation as a strategy for the strengthening of local "traditional" authorities. The institution of the chieftaincy is closely tied to the practice of linking political rights to the status as "native", which leaves the Dagara settlers on Sisala land represented if at all - only by a subordinate headman. But even the traditionally democratic majority vote to select assembly men and women can be influenced by informal pressure exerted by landowners in the context of candidate selection. In quite a few villages, settlers are openly pressured into not running for the assembly under threats to impede their access to land. The idea that close cooperation with "traditional authorities" guarantees grassroots democracy is naive. But hopes for easy alternatives are unwarranted.

One final comment: I do not wish to leave readers with the impression that the policy of decentralisation has caused the conflicts I just related. The underlying problems - the connections between land ownership and political authority, and the tension between ethnic and territorial criteria in defining local citizenship - are much older. However, the more narrowly the boundaries of the administrative units are drawn, the more acute the problems become of spatially and socially demarcating political communities.

\section{BIBLIOGRAPHIE}

Chauveau J.P., 2000, “Question foncière et construction nationale en Côte d'Ivoire”, Politique africaine $78: 94-125$.

Eyre-Smith R. St. J., 1933, A Brief Review of the History and Social Organisation of the Peoples of the Northern Territories of the Gold Coast, Accra : Government Printer.

Geschiere P., Gugler J., (eds.), 1998, "The politics of primary patriotism”. Special issue, Africa 68.

Geschiere P., Nyamnjoh F., 2000, "Capitalism and autochthony: the seesaw of mobility and belonging”, Public Culture 12: 423-52.

Kuba R., Lentz C., (forthcoming), “Arrows and earth shrines: towards a history of Dagara expansion in southwestern Burkina Faso", Journal of African History. 
Lentz C., 1995, “Unity for development': youth associations in north-western Ghana”, Africa 65 : 395-429.

- 1998, Die Konstruktion von Ethnizität. Eine politische Geschichte Nord-West Ghanas, 1870-1990. Köln : Köppe.

- 2000a, "Of hunters, goats and earth-shrines: settlement histories and the politics of oral tradition in northern Ghana", History in Africa 27 : 193-214.

- 2000b, "Contested identities: the history of ethnicity in northwestern Ghana", in: Carola Lentz and Paul Nugent (eds), Ethnicity in Ghana: The Limits of Invention, London : 137-61.

- 2000b, “'Chieftaincy has come to stay'. La chefferie dans les sociétés acéphales du Nord-Ouest Ghana", Cahiers d'Etudes Africaines 159 : 593-613.

- 2000c, "'Youth associations' et ethnicité au Nord-Ghana", in : Coumi Toulabor (éd.), Le Ghana de J.J. Rawlings. Restauration de l'État et renaissance du politique. Paris : Karthala : 126-44.

- 2001, “Ouessa. Débats sur l'histoire du peuplement”, in : Kuba, Richard, Carola Lentz and Katja Werthmann (eds.) : Les Dagara et leurs voisins. Histoire du peuplement et relations interethniques au sud-ouest du Burkina Faso. Frankfurt : Berichte des Sonderforschungsbereichs 268 Westafrikanische Savanne, 15 : 29-61.

- 2002, “'The time when politics came': Ghana's decolonisation from the perspective of a rural periphery", Journal of Contemporary African Studies 20.

Mamdani M., 1996, Citizen and Subject : Contemporary Africa and the Legacy of Late Colonialism. Princeton : Princeton University Press.

\section{NOTES}

1. NYDA, Petition for the Creation of a District for the Nandom Traditional Area, presented during the NYDA national delegates' conference, Dec. 1986: 6.

2. 3rd NYDA Delegates Conference, 29-30 Dec. 1986, minutes : 4.

3. Chief Commissioner Northern Territories to Colonial Secretary, 5 Nov. 1947, Regional Archives Tamale (RAT), NRG 8/2/101.

4. District Commissioner Lawra-Tumu to District Commissioner Wa, 1 Oct. 1947, RAT, NRG 8/2/101.

5. Lawra Conf. State Council, 4 May 1956, RAT, NRG 7/4/5.

6. NYDA, Petition for the Creation of a District for the Nandom Traditional Area, presented during the NYDA national delegates' conference, December 1986: 6.

7. Interview with Jacob Boon, Jirapa-Lambussie District Commissioner, 23 Nov. 1989.

8. Letter signed by “Tribal Heads" of the Dagarti, Moshi, Wala, Wangara, Grunshi, Kantosi, Zambrama and Fulani to District Secretary Lawra, 31 March 1987.

9. The District Secretary obviously followed the Lambussie Kuoro's version who used to speak of a "High Court decision" on the Hamile affairs; in fact, the case was never brought before the High Court, but decided by a native authority court, namely the Lawra Confederacy Court A.. See RAT, NRG 7/2/5 for the Lawra Confederacy Court Book with verbatim extracts of the court case in 1950, and an appeal in 1951.

10. Lawra District Secretary to Lambussie Kuoro, Nandom Naa and others, 5 May 1987.

11. Kokoligu Naa Michael Sovera et al to District Secretary Lawra, May 1987.

12. People's Daily Graphic, 11 July 1987. 
13. Lambussie Kuoro, K.Y. Baloro, and Secretary Issaw West Development Union, Jacob Boon, to NCD, PNDC Regional Secretary, Wa, and District Secretary, Lawra, August 1987.

14. NYDA National Executive to PNDC Regional Secretary, 2 Sept. 1987.

15. "Summary of decisions taken at a meeting of Lambussie Kuoro, Nandom Naa and their respective Tindanas with His Grace Archbishop P.P. Dery", Hamile, 23 Jan. 1990.

16. See the minutes of the District Security Committee visit to Taalipuo, 5 May 1988.

17. Interview with the NYDA executive, Wa, 15 Nov. 1990.

18. Upper West Regional Secretary to Ag Director Castle Information Bureau, Accra, 10 May 1989.

19. NYDA National Chairman to Ag. Director, Castle Information Bureau, 26 May 1989.

20. NYDA National Chairman to Upper West Regional Secretary, 8 Feb. 1988.

21. People's Daily Graphic, 27 May 1989.

22. Interview of 28 Nov. 1989, Lambussie.

23. Interview of 17 Nov. 1990, Tamale.

\section{AUTEUR}

\section{CAROLA LENTZ}

Paper to be presented at the APAD conference, May 2002, Leiden, Institut für Ethnologie und Afrika-Studien, Universität Mainz, Forum 6, D 55099 Mainz. 